\title{
English Achievement and Bullying in Junior High School Students
}

\author{
Amalia Rahmawati ${ }^{1}$, Dewi Hartinah ${ }^{1}$, Faza llya ${ }^{1}$ \\ ${ }^{1}$ Universitas Muhammadiyah Kudus \\ Email:amalia@umkudus.ac.id
}

\begin{abstract}
This is mixed method research with qualitative and quantitative data. The qualitative data comes from interview while the quantitative data comes quantitative data comes from correlation analysis data between the English score and the result of bullying questionnaire. The qualitative comes from interview data, while the quantitave data comes from the students achievement in English subject. The population of this study is 230 students with 146 students as sample. The sampling techniques done by using random sampling They come from class VII SMP Muhammadiyah Kudus because the adolescent have increased pressures, increased decision making, and the search for self. This research was bivariate analysis with Spearmen Rank Test and the instruments were in-depth interview, questionnaires, the daily test scores in English. The result of quantitative data showed that there was a moderate correlation between bullying behavior and English achievement for junior high school students with $\mathrm{p}$ Value $=0.000<\boldsymbol{\alpha} 0.05$ and $\mathrm{r}$ value -0.470 with moderate strength and having negative relationship direction. The bullying affects the English achievement in term of motivation to study English. Based on qualitative data, the students become embarrassed and afraid when they speak and learn English because pronouncing English word is hard for them.. This condition happens because their friends and teacher mock them. It can be concluded that there is a correlation between bullying and English achievement for Junior High School.
\end{abstract}

Keywords: English achievement, Bullying, Junior high school students

\section{INTRODUCTION}

The Indonesian Child Protection Commission (KPAI) noted that from 2011-2014 there were 369 complaints regarding bullying. This figure is around $25 \%$ the total complaints in the education sector of 1,480 cases. Bullying is what the KPAI calls a form of bullying in schools, defeating student brawls, educational discrimination or complaints about illegal levies. Based on the Details of the Child Complaint Case Data Table Based on the
Child Protection Cluster of the Indonesian Child Protection Commission (KPAI) 2011-2016, it shows that there were 159 cases of child victims of school bullying in 2014, 154 cases in 2015, and 97 case in 2016. For cases of children as perpetrators of school bullying in 2014 there were 67 cases, in 2015 there were 93 cases, and in 2016 there were 112 cases(Nurlia \& Suardiman, 2020).

Increasing the education quality becomes the big project for all of the country in the world. 
They believe that the key to the future of a nation is determined by the existence of a quality education system, which is shown by quality schools. One of the indicators to measure the quality of education is by students' achievement. That phenomenon happens in all of the educational level start from primary school until university level. One of the subjects in junior high school is English. English becomes the most important global language in developing countries such as Indonesia. (Sabil, 2020)

English is a subject that is usually a scourge for some students. This is because English is not a lesson that can be understood only by reading and memorizing it. Students need to practice four skills in English, such as listening, speaking, reading and writing (Bonell et al., 2018)aggression, and violence among children and young people are some of the most consequential public mental health problems. We tested the Learning Together intervention, which involved students in efforts to modify their school environment using restorative practice and by developing social and emotional skills. Methods: We did a cluster randomised trial, with economic and process evaluations, of the Learning Together intervention compared with standard practice (controls

Schools are formal educational institutions, which function and aim to gain knowledge that changes the students become good people who has broad insight and becomes a provision for the future. Currently, education problems arise in Indonesia. We often find information on social media that there are many cases of bullying in schools. One of the acts of bullying that often occurs is not only physically but psychologically as well. Such as isolation from friends or often referred to as bullying. The phenomenon of bullying like this is an unbroken chain. Children who have experienced bullying will experience long-term emotional fear and anxiety (Oliveira et al., 2018)

Bullying is aggressive behavior unwanted by other children which can result in repeated physical, psychological or social damage, which often occurs in schools and other places where children gather, including social media. Bullying is an act of bullying or intimidation of other children both physically and verbally and there is usually an imbalance of power between the perpetrator and the victim of bullying. Bullying becomes one of the serious problem because oung person's suicide death linked in some way to bullying. (Hosseinmardi et al., 2015)

The results of a survey conducted by the Semai Jiwa Amini (SEJIWA) foundation in an antibullying workshop attended by approximately 250 participants found that $94.9 \%$ participants stated that bullying does occur in Indonesia. SEJIWA's research in three major cities in Indonesia, namely Yogyakarta, Surabaya and Jakarta, recorded a level of bullying of $66.1 \%$ at the junior high school level. Bullying committed among students was recorded at $41.2 \%$ for junior high school level with the highest category of psychological bullying in the form of exclusion. The second rank is occupied by verbal bullying such as taunting and finally physical bullying. The top three city of bullying in junior high schools are Yogyakarta 77.5\%; Surabaya 59.8\%; and Jakarta 61.1\% (Fadillah, 2014)(Khasanah \& Sirodj, 2019). Bullying becomes the major problem 
in teenager because of the characteristics of teenager (Kao et al., 2019).

In Central Java Province itself, many cases of bullying occurred in schools. Data from the Central Java Provincial Education Office shows that bullying in schools is still around 5\%. Some reasons for the lack of attention in cases of bullying in schools are: First, the effect is not direct, except for bullying in the form of physical bullying. Second, there are many cases of bullying that in plain view look like ordinary jokes typical of school children or adolescents which are thought to have no serious impact. Verbal taunts and banters fall into this category. Many parents and teachers think that just a reprimand may be enough to solve the problem. In fact, the psychological and emotional wounds experienced by victims of verbal bullying are much deeper and painful. Third, some parents and teachers still do not have adequate knowledge about bullying and its impact on children's lives. So that some parents and teachers really don't know that there is a serious problem around them. All forms of bullying received by students will affect their mental state in terms of physical health, psychological health, social health, and personal health(Jan MPhil Scholar \& Husain Assistant Professor, 2015)the person who bully, those who are victims, and the persons who witnesses to interpersonal violence. Bullying may include verbal and physical assaults, threats, 'jokes' or language, mockery and criticizing, insulting behavior and facial expressions. These factors work individually, or collectively, to contribute to a child's likelihood of bullying. Bullying is difficult to eradicate in schools because it is so often effectively used by students. Teachers as professionals have to deal with the consequences of pupil-on-pupil bullying. The impact of prejudice-related bullying should not be underestimated. Bullying must be recognized, understood and taken seriously. The major objectives of this study were (i(Van Werf, 2014) .Yayasan Semai Jiwa Amini (SEJIWA, 2008) explained that students who receive pressure will show symptoms such as the onset of fear, anxiety, depression, low self-esteem, worthlessness (Hosseinmardi et al., 2015) and also have lower academic achievement and drop out of school (Kao et al., 2019) Decreased self-confidence can result in social behavior where they tend not to socialize with their environment. In addition, students who are victims of bullying will have less interest in going to school, have difficulty thinking clearly so that their academic achievement can be threatened with decline (Erika et al., 2017)(Nurlia \& Suardiman, 2020)

In teaching and learning process, students should able to learn effectively and have fun with their friends. This ideal situation is difference with the reality. Students feel nervous and embraced when speaking practice because pronouncing English word is not easy for them. It also relates to the way in speaking in the students' mother tongue. In their mother tongue, some of phonetic are different with English phonetic. When they speak, they have to think the translation word, the pronunciation of the word and also how to pronounce it fluently. Moreover, those condition needs high effort. Their effort to learn English is not in line with the condition when their friends mock them.

Based on the description above, dealing the bullying experience and English achievement in the 
junior high school students is important to create the English teaching and learning process.

\section{METHOD}

This mix method research employs both qualitative and quantitative data. The quantitative data comes from correlation analysis data between the English score and the result of bullying questionnaire, while the qualitative data comes from interview data. The students who are as the sample of the research also as the interviewee. The population of this study was 230 students in Class VIII SMP Muhammadiyah 1 Kudus. The sample technique was simple random sampling with 146 students. The instrument of quantitative research was the bullying questionnaire and the students score. The questionnaire is based on questionnaire bullying Olweus Victim that has been modified. There are 25 questions with linkert scale. The questions are divided into favourable and unfavourable questions. Moreover, the qualitative data comes from openended interview question. The quantitative data was analyzed based on univariate and bivariate analysis. The univariate analysis used in order to describe the data, while the bivariate analysis used with Spearman Rank test.

\section{FINDINGS AND DISCUSSION}

Based on the analysis, the age of respondents are 12 - 16 years old with $88(60,3 \%)$ male students and $58(39,7 \%)$ female students.
Table 1. Bullying and English Achivement

\begin{tabular}{|c|c|c|c|c|}
\hline No & Item & Cathegory & Total & Percentage \\
\hline \multirow{3}{*}{1} & \multirow{3}{*}{ Bullying behaviour } & Low & 32 & 21,9 \\
\hline & & Moderate & 75 & 51,4 \\
\hline & & High & 39 & 26,7 \\
\hline \multirow{2}{*}{2} & \multirow{2}{*}{$\begin{array}{l}\text { Bu } \\
\text { Ilying cathegory }\end{array}$} & Verbal & 94 & 97 \\
\hline & & Physis & 52 & 44.5 \\
\hline \multirow{2}{*}{3} & \multirow{2}{*}{ Sex } & Male & 92 & 60.3 \\
\hline & & Female & 54 & 39.7 \\
\hline \multirow{2}{*}{4} & \multirow{2}{*}{$\begin{array}{l}\text { English } \\
\text { achievement }\end{array}$} & Less & 101 & 69,2 \\
\hline & & Good & 45 & 30,8 \\
\hline
\end{tabular}

Based on table 1, it shows most of bullying behaviour done by the students are in the moderate category. There are 75 students or $51,4 \%$ of respondents as the victim in the bullying experience. Moreover, the lowest percentage of bullying behaviour is in the low category with 32 students or $21,9 \%$ of students. The category of bullying bahavior is done by scoring the questionnaire. Based in the type of bullying, $97 \%$ of students or 94 students belongs to verbal bullying belongs to verbal bulling while the rest are physic bullying. However the verbal score is higher, but sometimes they also do both. Students in SMP 1 Muhammadiyah 1 Kudus did the bullying in term of mock their friends, such as by asking "fat, thinny, sissy, etc". Those bullying focuses on the physical appearance. Bullying has big effect especially if the children often got bullying, they will have extreme instability and unhappiness in the adolescence

Based on the sex category, the biggest sex who had bullying behaviour is 92 male students or $97 \%$ of students and $39.7 \%$ of them are female. Most of the male students when they play with their 
friends, sometimes they do bully with their friends. Their bullying phenomena belongs to intermediate category occurs when a person experienced in form of systematic and convincing harassment and humiliation in a long time. Their actions include cruel taunts, excommunicated, and several threats, excommunicated, and subtle physical attacks, for example pushing, tackling, pulling clothes, etc. The bullying behaviour is affected by the school management, students behaviour and the environmental factor. Moreover, teacher also has the main role in the bullying behaviour in school. It happens because teacher should be able to manage the students and and manage theirselver. Some of students also feel that their teachers did bully to them in teaching and learning process. These conditions become a big problem because it can affect the students' achievement(Oliveira et al., 2018)(Khasanah \& Sirodj, 2019).

Based on table 1, the students' achievement category, there were 101 students or $69,2 \%$ of students in SMP 1 Muhammadiyah Kudus belongs to less category and 45 students or $30,8 \%$ of students in SMP 1 Muhammadiyah Kudus. The students who are in the less category because their English score is less than minimum criteria competence $(<65)$.

Qualitatively, the English achievement also affected by their motivation in learning English. Based on the research, most of the students did not have confidence in pronouncing English word because they fear of being wrong and laughed by their friends. Based on the interview data, most of the students said that
Table 2. The Students' Statement in the qualitative data

\begin{tabular}{|l|c|}
\hline \multicolumn{1}{|c|}{ Statement } & Percentage \\
\hline $\begin{array}{l}\text { "I am embrassed when I speak English, my } \\
\text { friends laugh me" }\end{array}$ & $18 \%$ \\
\hline $\begin{array}{l}\text { "I am afraid to speak because it is difficult to } \\
\text { pronounce English" }\end{array}$ & $20 \%$ \\
\hline $\begin{array}{l}\text { "I confuse because I don't know the meaning } \\
\text { of English words. So, usually my friends laugh } \\
\text { me because I have wrong word" }\end{array}$ & $17 \%$ \\
\hline $\begin{array}{l}\text { "My friends always mock me, because usually I } \\
\text { do wrong in pronouncing the English word. }\end{array}$ & $13 \%$ \\
\hline
\end{tabular}

The qualitative data is in line with the quantitative data that their English achievement is low because of the bullying behaviour. The English achievement is also supported by their motivation. If they did not have motivation because of afraid and embrassed, their achievement also will be affected. In teaching and learning process, motivation becomes the big thing that must be had by the students. Motivation consists of three elements such as effort, desire and affect. Effort means that spending time to study. Desire means how much the learner wants to become proficient in the language, and affect means the learner"s emotional reactions related to study language. Moreover, English achievement is also supported by their study behaviour (Purwanti et al., 2019). 
Amalia Rahmawati, Dewi Hartinah, Faza llya

English Achievement and Bullying in Junior High School Students

DOI: https://doi.org/10.31605/eduvelop.v4i2.977

Table 3. The Correlation between Bullying and English achievement in SMP Muhammadiyah 1 Kudus

\begin{tabular}{|l|r|r|r|r|r|r|r|r|}
\hline \multirow{2}{*}{ Bullying } & \multicolumn{4}{|c|}{ English Achivement } & \multicolumn{2}{|c|}{ Total } & \multirow{2}{*}{ R } & \multirow{2}{*}{$\begin{array}{c}\text { p } \\
\text { value }\end{array}$} \\
\cline { 2 - 7 } & \multicolumn{2}{|c|}{ Less } & \multicolumn{2}{|c|}{ Good } & \multicolumn{2}{|c|}{} & & \\
\cline { 2 - 7 } & $\mathrm{n}$ & $\%$ & $\mathrm{n}$ & $\%$ & $\mathrm{n}$ & $\%$ & & \\
\hline Low & 10 & 31,3 & 22 & 68,8 & 32 & 100 & & \\
\hline Moderate & 54 & 72,0 & 21 & 28,0 & 75 & 100 & \multirow{2}{*}{0,470} & 0,000 \\
\hline High & 37 & 94,9 & 2 & 5,1 & 39 & 100 & & \\
\hline Total & 101 & 69,2 & 45 & 30,8 & 146 & 100 & & \\
\hline
\end{tabular}

Based on table 3, in the high bullying category, their English achievement belongs to less category is 37 students or $94.9 \%$ and belongs to good category is only 2 students or $5.1 \%$. Moreover, in the low bullying category, their English achievement belongs to less category is 10 students or $31 \%$ and belongs to good category is 22 students or $68.8 \%$.

Based on Spearman's Rho analysis, it can be seen that $p=0,000<\alpha 0,05$ and $r$ value is $-0,470$. The $r$ value is around $\mathrm{r}=0.40-0.599$ (the correlation is in the medium level) and it has negative correlation. It can be concluded that there is a strong relationship between bullying behavior and English learning achievement with the moderate category for students in SMP Muhammadiyah 1 Kudus. Students who become bullying victim will send their time to avoid the distraction at school, especially in the teaching and learning process. Therefore, they have less energy to study English. This condition will affect the English learning achievement. Students who become bullies have low achievement, act against violence and anarchism, often skip school and have attitudes that challenge both parents and adults. Students who become bullies and victim bullying have low achievement, act against violence and anarchism, truancy school and etc (Fadillah, 2014).

The high percentage of bullying accident done by the students in SMP Muhammadiyah Kudus does not mean hurt the friends physically and psychotically, but they only want to have fun with their friends. This finding is in line with Hamuddin, B etc (2019), that some students do bullying in order to have fun and make a joke with their friends. Although it is only a joke, the effect of bullying still make impression for the them.

Bullies tend to get low academic achievement and they dislike school. They also got rejection from peers because the offender's aggressive values do not align with the majority of the group. These differences can lead to rejection from peers and displeasure from the teacher which in turn can lead to the offender becoming affiliated with other aggressive children. This kind of behavior often causes children to experience learning difficulties and low academic achivement.

There are several factors that influence English acvhivement such as internal factor and external factor. The internal factor means factor comes from the students, while the external factor comes from school environment and social environment. Besides that, the factors that influence learning achievement are not only due to the school environment where bullying is present but also other factors such as learning methods.

\section{CONCLUSION}

English becomes one of the difficult subject for Junior High School students. Students feel 
difficulties in learning English because they not only need to read and memorize the word but also need to practice in speaking and writing. Based on the analysis, there are 75 students or $51.4 \%$ of students have moderate bullying behaviour and 101 students or $69.2 \%$ of students have less category in English achievement. And it can be concluded that there is a relationship between bullying behavior and English learning achievement of students at SMP Muhammadiyah 1 Kudus, with $p$ value $=0,000$ and a value of $r=-0.470$ having a moderate correlation and having a negative relationship direction. It can be seen from the qualitative data that the students feel embrased when speaking English and afraid to speak English. The high percentage of bullying happens, it does not mean that the students want to hurt their friends physically or psychologically. They only want to have fun and make a joke with their friends. Although their purpose is only that, the effect of bullying can affect the students' learning motivation and reduce the students' English achievement. It is recommended for the teacher to manage their students in the teaching and learning process.

\section{REFERENCES}

Bonell, C., Allen, E., Warren, E., McGowan, J., Bevilacqua, L., Jamal, F., Legood, R., Wiggins, M., Opondo, C., Mathiot, A., Sturgess, J., Fletcher, A., Sadique, Z., Elbourne, D., Christie, D., Bond, L., Scott, S., \& Viner, R. M. (2018). Effects of the Learning Together intervention on bullying and aggression in English secondary schools (INCLUSIVE): a cluster randomised controlled trial. The Lancet, 392(10163), 2452-2464. https:// doi.org/10.1016/S0140-6736(18)31782-3
Erika, K. A., Pertiwi, D. A., \& Seniwati, T. (2017). Bullying Behaviour of Adolescents Based on Gender, Gang and Family. Jurnal Ners, 12(1), 126. https:// doi.org/10.20473/jn.v12i1.4396

Fadillah, R. (2014). Learning Motivation and English Achievement of Students At Politeknik Negeri Semarang Central Java. Jurnal Penelitian Humaniora, 15, 89-98.

Hamuddin, B, etc.(2019). Do They Truly Intend to Harm Their Friends?: The Motives Beyond Cyberbullying among University Students. International Journal of Cyber Behavior, Psychology and Learning. https://doi. org/10.4018/IJCBPL.2019100103

Hosseinmardi, H., Mattson, S. A., Rafiq, R. I., Han, R., Lv, Q., \& Mishra, S. (2015). Analyzing labeled cyberbullying incidents on the instagram social network. Lecture Notes in Computer Science (Including Subseries Lecture Notes in Artificial Intelligence and Lecture Notes in Bioinformatics), 9471(March), 4966. https://doi.org/10.1007/978-3-319-27433-1_4

Jan MPhil Scholar, Msa., \& Husain Assistant Professor, S. (2015). Bullying in Elementary Schools: Its Causes and Effects on Students. 6(19), 43-57.

Kao, H. Te, Bartley, N., Yan, S., Hosseinmardi, H., Huang, D., \& Ferrara, E. (2019). Understanding cyberbullying on instagram and Ask.fm via social role detection. The Web Conference 2019 - Companion of the World Wide Web Conference, WWW 2019, 183188. https://doi.org/10.1145/3308560.3316505

Khasanah, A. N., \& Sirodj, D. A. N. (2019). Types of Bullying in Junior High School Students. January. https://doi.org/10.2991/sores-18.2019.50

Nurlia, A., \& Suardiman, S. P. (2020). The phenomenon of bullying in junior high school students nowadays. International Journal of Education and Learning, 2(1), 7-13. https://doi.org/10.31763/ijele.v2i1.62

Oliveira, F. R., de Menezes, T. A., Irffi, G., \& Oliveira, G. R. (2018). Bullying effect on student's performance. EconomiA, 19(1), 57-73. https://doi.org/10.1016/j. econ.2017.10.001 
Amalia Rahmawati, Dewi Hartinah, Faza Ilya

English Achievement and Bullying in Junior High School Students

DOl: https://doi.org/10.31605/eduvelop.v4i2.977

Purwanti, D., Puspita, H., \& . M. (2019). the Correlation Between English Learning Motivation and English Proficiency Achievement of English Study Program Students. Journal of English Education and Teaching, 3(1), 79-94. https://doi.org/10.33369/jeet.3.1.7994
Sabil, M. (2020). The Use of Task-Based Language Teaching in Improving Students 'Speaking Proficiency. 4(1), 31-36.

Van Werf, C. Der. (2014). The Effects of Bullying on Academic Achievement. Desarrollo y Sociedad, 74, 275-308. https://doi.org/10.13043/DYS.74.6 